\title{
I BELIEVE SO THAT I MIGHT UNDERSTAND: AN EPISTEMIC STUDY ON THE RELATION OF BELIEF TO KNOWLEDGE IN SAINT AUGUSTINE
}

\author{
As. Prof. Dr. Halil KAYIKCI \\ BINGOL UNIVERSITESI TURKEY \\ halilkayikci@hotmail.com
}

DOI:10.5901/mjss.2014.v5n19p307

\begin{abstract}
If we weren't creatures hungry to believing, we could not reach to the belief. The confirmation of the need to believing depends upon the mind's awareness of its limits. Life is so short that, if we wait all of our questions to be answered, our life does not suffice. Probably no people live so long to get immediate and individual knowledege of all truths. Besides, belief is brought to be necessary by the constraints of human knowledge. Non of us never can be in a stuation in which we can know every thing immediately. Every time there are a great many truths that should be approved depending on the testimony of some authorities. We know much more thing via belief than that we know via experience untill now and those things are much more important from the point of our spiritual and wordly happiness. Once we decide not to believe any thing that we comprehend by means of our senses, than no human institution can remain robust. Faith also stands in the foundation of love and respect. As paralel to his those thoughts, Augustine's understanding of knowledge is opposite to the contemporary empirical understanding. Contemporary empirical understanding allocates knowledge to the assertions which are believed by people depending upon a robust evidence when they are true. However, for Augustine (AD 354-430), basic knowledge is belief. Belief is necessary, because it's antecedent to understanding temporarily. The person who don't believe will not understand. Because the people who don't believe will not experience and the people who don't experience will not know. It's our duty to understand what we believe in sincerely and to get sight of rationality of our belief. Understanding is not only getting an additional evidence for belief to justify belief, but also in understanding foundations of belief or meaning of the thing believed or both of them become more robust.
\end{abstract}

Key Words: Augustine, belief, faith, knowledge, understanding, the relation of belief to knowledge, the relation of belief to understanding.

\section{Introduction}

Augustine's view to the concepts of belief and knowledge and relation he sets up between these concepts are characteristic for both his general philosophy and his philosophy of knowledge. For him knowledge and the belief' relation to knowledge have an importance beyond the practical life. That all data we have do not have the characterisric of knowledge and also we own beliefs and also although those beliefs we own are different from the point of both their construction and the way they are obtained, they are inevitable for us, because they constitute an important part of our life and our actions, to investigate the structure and characteristics of the concept of belief and the relation of belief to knowledge are extremly important both from the point of philosophy of knowledge and religious and daily life.

As a person who struggled with scepticism, Augustine, in addition to knowledge, argues that "belief is the only likely treatment for his spiritual condition." ${ }^{1}$ With the words of Schmitt, "belief is necessary for the rational order of things. If scepticism was confirmed, the intelligible and harmonious structure of the world became scattered." ${ }^{2}$ Nash also indicates to the same point but he does this coming up with some conditions. According to him, "it's necessary for us to believe in something but we should direct our belief to the objects that are most worthy to believe." 3 The reason for his thinking like this, on the other hand, is to establish the credibility of religious and ethical facts. In this issue, "Augustine may be affected

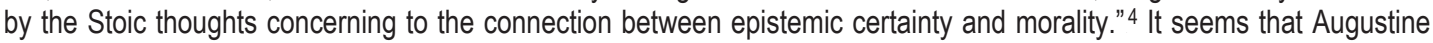

\footnotetext{
${ }_{1}^{1}$ Stephen Menn, Descartes and Augustine, Cambridge 2002, p. 187.

${ }^{2}$ Charles B. Schmitt, Cicero Scepticus: A Study of The Influence of The Academica in the Renaissance, The Hague, Martinus Nijhoff, 1972, p. 148.

${ }^{3}$ Ronald H. Nash, The Light of The Mind: St. Augustine's Theory of Knowledge, Ohio 2003, p. 22.

${ }^{4}$ Gerard O'Daly, "The Response to Scepticism and the Mechanism of Cognition", The Cambridge Companion to Augustine, Cambridge 2006, p. 164.
} 
appriciates the social and practical necessity of belief. Whether we are conscious of or not, our basic relations are based on our beliefs. In this meaning, association of scepticism about the ability of human reason's obtaining knowledge with a belief pertaining to the truth itself, made lead Augustine to the conclusion that the only way of solution was faith or belief. For this reason, he proposes the analysis of many kinds of credibility: Facts to be believed. Firstly, we have historical truths in which we can only believe, because we don't have any immadiate, first hand knowledges about them. He attracts attention to that we know execution of Catinean assassins only through the authority of Cicero (106-43 BC). This authority is robust like authorities depending on them we know who our parents are. It would be nonsense to reject having respect for our parents, by asserting that we don't know who they are. Augustine was affected by the fact that some of the most basic relations -love of child for parents and affinity of friends and married couples each other- depend upon reliable

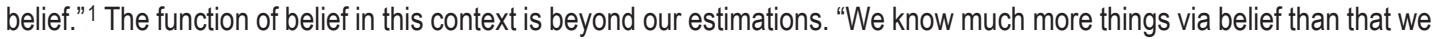
know via experience untill now and those things are much more important from the point of our spiritual and wordly happiness. Once we decide to do not believe any thing that we can not comprehend by means of our senses, than no human institution can remain stable. The trust that is at the root of faith is also at the root of friendship, love and respect that are the foundations of society." ${ }^{2} \mathrm{He}$ gave priority to belief but didn't neglect the importance of knowledge. "Throughout his writings he insist that knowledge is not to be sought for its own sake; instead man should seek knowledge so that through it he may attain true happiness. Augustine's view is not so much that knowledge will make the attainment of happiness easier but that the knowledge of absolute truth is a necessary condition for happiness. Although Augustine's practical interest in knowledge keeps him from giving us the kind of systematic discussion of certain topics that one finds in Hume or Kant, there is nonetheless a certain benefit that follows. The fact that knowledge is related to God and to human quest for happiness insures the importance of epistemology for Augustine."3

\section{Knowing By Seeing And Knowing By Believing}

In this context he firstly seperates knowing to two categories as knowing by way of belief and knowing by way of knowledge (seeing) and examining how they can be obtained questions their reliability. According to him, in knowing by the way of belief there is not the credibility that is in knowing by way of knowledge. "The first Augustine calls belief (the way of faith) and the second he calls "understanding" (the way of reason). Both modes of knowing seek to bring about the union between knower and the thing known which is the essence of knowledge. In the case of understanding there is an immediate contact between the two, a direct confrontation in which the knower perceives the objectby a type of 'vision'. Since my experience of such truths is so immadiate, they seem to force themselves upon me. I can not deny the pain in my leg nor the noise of the street nor the remembered facts of my past. I may try to ignore them but I can not deny them once they capture my attention. Moreover, once attended to, they have a tendency to move me by their presence. My contact is so intimate that once I see them as true, I easily move to see them as good or bad. I quickly move from being a knower to a lover, reaching out to embrace those realities which promise to bring satisfaction and happiness when possessed." 4

Knowing by the way of belief is very different from the other way. "Knowledge by the way of belief (faith) does not possess such power. The truth of the object known is not known directly but only through the testimony of ohers. Whatever is good and desirable about the object is known by hearsay, not vision. The immadiate contact of the knower is with that witness who testifies to the truth perceived. It is not the truth of the object that forces itself upon knower. It is the credibility of witness, a credibility that rest on a conviction that this witness is (1) knowledgeable, that is, is in a position to know the facts and (2) trustworthy, that is, is not likely to misrepresent the facts. Only rational beings can serve as such witnesses and since humans, angels and God are wrapped in mystery, we are never overpowered by evidence of credibility unless we want to be. It is for this reason that Augustine will define faith or belief as an act of thinking with assent" 5 Helm argues that this uncertainty which exist in the conceps of belief and faith is a necessary result of the structure of these concepts. According to Helm, "without risk there is no faith. Faith is precisely the contradiction between the infinite passion of the individual's inwardness and the objective uncertainty. If I am capable of grasping God objectively, I do not believe, but precisely because I can not do this I must believe. If I wish to preserve myself in faith, I must constantly be intent upon

\footnotetext{
1 John M. Rist, Augustine, Ancient Thought Baptized, Cambridge, 1997, p. 56.

2 Donald X. Burt, Augustine's World, London, 1996, p. 45.

${ }^{3}$ Ronald H. Nash, Ibid., p. 22.

${ }^{4}$ Donald X. Burt, Augustine's World, London, 1996, p. 44

5 Ibid., p. 44.
} 
holding fast the objective uncertainty, so as to remain out upon the deep, over seventy thousand fathoms of water, still preserving my faith." 1 This view can be striking for believers like us but it is clear that it may help us seriously to understand some of the most essential concepts we have. "On this view faith is inherently risky, not because there is in fact little evidence for what is believed and more would be desirable, but because whatever evidence there is is in some way against the truth of the proposition believed, and thus faith 'contends' with evidence against. It is a mistake to think that such a view of faith cannot be defended; it does not follow that there are no reasons for holding the view that religious faith is not reasonable." ${ }^{2}$ As we saw here, for a thinker who adherent to the Platonic tradition, to think on the borders of our knowledge helps only reevaluation of the lower position of belief and identify the credible authorities.

Augustinus rethorically makes a sharp seperation between the exactness of knowledge and baseless structure of belief. "Despite his positive expressions about belief such as rational, proven and worthy of trust, he argues that belief has not the first hand proofs that knowledge has. Besides, it is out of immediate proof which sense perception has. A wellapproved sense perception is a form of knowledge, in the meaning that historical testimony never become." ${ }^{3}$

Nevertheless, the concept of faith enters into our lives indispensably, because when it requires to know the truth, though the human mind is necessary, it is not sufficient. According to Augustine, "the created light of human mind requires a light from outside. Even created intelligible light could not explain the human knowledge without unchanging, immanent and active being of God. But the light with which the human soul is illuminated is different. Such that the soul by oneself or in that light can see every thing through reason and truly. Because the light is God' itself. Nevertheless, every thing that the soul grasp or can grasp via reason spring up from that light." 4

The use of the concept of faith embraces both the issues about God and issues about external world. "Faith is the response to God's self revelation and the only access to God as trinity. By faith persons communicate with God, who communicatd with them by creation and by sending the Son and Spirit." ${ }^{\text {Human }}$ transceds the world with that act of faith. "The act of faith belongs to the rational (practical) mind, which focuses on the temporal Christ, his life, words, death and resurrection. Human beings ascend from knowledge (scientia) in this temporal life to wisdom (sapientia) in eternal life where God is contemplated." 6

But, as we said, faith is not peculiar only to religion. According to Nash, "Augustine raises an additional argument, however, in claiming that faith is not peculiar to religion. It is, in fact, indispensable in every area of life. To take a simple example one's knowledge of his own identity depends upon faith, for how else would one know that the people who claim to be his parents really are unless he either trusts their word or the word of someone else? Moreover, all learning depends upon faith. If we refused to believe things that we have not experienced personally, we could never know the facts of history, which are based upon the testimony of others whom we take to be authorities. This, Augustine insists, is faith."7

Paul Helm, in his book called Faith and Understanding, in which he investigates these issues elaborately, speaks of these two meanings of faith and exemplify Augustine' use of faith concerning world we mentioned before under the names of individual and propositional faith. For Helm, "faith can be used in at least two quite distinct senses, and each sense is important. The Word can be used as shorthand for 'the faith', that is, for a body of beliefs of a theological or religious character which forms the cognitive content, or the core of the cognitive content, of some recognizable religion. Thus it is part of the faith of Jehova's witness that they believe that Jesus Christ is a creature, whereas it is part of the faith of a Christian that they believe that Jesus Christ is God. When man and women confess their faith, whether they are Muslims, Hindus or Christians, then what they are confessing is the set of propositions, together with the associated practices, which they regard as essential to their faith and which includes those beliefs which are distinctive of it. And the reason why this body of propositions is referred to as the faith is, quite simply, that it is that set of propositions which express what the holders regard as trustworthy truths about God, about themselves in their relation to God, and so on. One could use 'faith' in this sense to refer to the convictions of an atheist, for the atheist also has a set of beliefs. Naturally, being an atheist, he does not include in this set any beliefs which he believes imply the existence of God. Nevertheless an atheist may, in this sense, be said to have a faith... Such faith involves understanding, for a person can hardly believe what he

\footnotetext{
1 Paul Helm, Faith and Understanding, Michigan 1997, p. 14.

2 Ibid., p. 14-15.

3 Gerard O'Daly, Ibid., p.164.

${ }^{4}$ Augustinus, De Genesi Ad Litteram XII, 31, 59.

${ }^{5}$ Mary T. Clark, "De Trinitate", Cambridge Companion to A ugustine, Cambridge, 2006, p. 97.

6 Ibid., p. 99.

${ }^{7}$ R. H. Nash, Ibid., p. 25.
} 
does not to some degree understand. But he may not understand it very much and may seek to understand it more. Increased understanding of the propositions of the faith enhances the way of faithas a whole. It is sometimes suggested that there is a sense of faith which which is 'personal' and which is to be contrasted with a 'propositional' sense of 'faith'. But this distinction does not seem to be a watertight one. If my friend Jones says that he will lend me his ladders and I believe what he says, then my reliance upon him - my faith - must have both a propositional and personal aspect to it. I believes Jones. I may or may not give him unconditional belief, believe him whatever he says. But what is undeniable is that I believe him in respect of the ladders. The proposition expressed by the sentence 'Jones will lend Helm his ladders' is believed by Helm because it is taken to be a trustworthy assertion of Jones. In believing the proposition, I believe - trust - the person, and in believing the person on this occasion I believe what he says, his utterance about the ladders. So the two senses of faith, the personal and the propositional, are interconnected, and highlight two aspects of one stuation. Though, understandably enough, the faith of an atheist cannot have this personal aspect, since he cannot regard the propositions of his faith as being the personal statements of anyone."1

While this long quotation is noteworthy from the point of being explanatory, it still does not hold forth explanation enough concerning to the relation of the concept in question to knowledge. The responce of this question lies in the seperation we made above. According to Nash, "as long as faith is understood in the first sense noted - as acceptance of authority or indirect knowledge - the it is true by definition that faith plays no role in immadiate scientia. There are two obvious examples of this kind of knowledge. One can know his own soul directly by intuition and one can perceive sense objects directly. It would be a contradiction to assert that faith (in the sense of being considered) plays any role in my present perception of a sensible object."

I think, we can solve this contradiction by examining the other meanings of this concept. "There is another sense of the word in which faith does play a part in immediate scientia, at least in sense perception. Unless one assumes or presupposes that the senses are reliable, he will not regard the information received through them as knowledge. The Academician's depreciation of sense perception is proof of this. One need not be or aware of the confidence he has in the senses, for example, but when he becomes conscious that he no longer trusts their reports, they will no longer be regarded as a source of knowledge. Thus if faith is understood as the act of assuming (consciously or unconsciously) that something is the case, there is a sense in which it is indispensable, even for immediate scientia. A knowledge of anything depends somewhat upon one's presupposing certain other things. This is, of course, most clear in geometry, where there can be no knowledge untill certain axioms and postulates are assumed. This is just as true of other areas of knowledge. For example, The Thomist thinks he can reason his way to God's existence without faith. Perhaps he can, in a particular way, he would not succeed if he had no confidence (faith, in another sense of the word) in the reports of his senses or in the laws of logic."3

What we have explained untill now can be assumed to prove that Augustine believed that a real philosophy was in the same time was a real theology. His that belief puts in the words a common quality of middle age philosophy. Moreover, he was at the beginning and foundation of an understanding that dominated to the middle age. In middle age philosophy, faith and reason were not activities that could be investigated seperately from each other, they were not psychologically different activities. For this reason, that Augustine's use a religious concept in explaining philosophical subjects is not an extraordinary stuation. If we deal with in the context of our subject, Augustine states this truth by saying 'I believe, so I can understand.' The reason for that he states question so, is that faith and reason both two are necessary elements of knowledge. With these expressions, Augustine made faith, or as sometimes used belief, necessary component of philosophy of knowledge. This situation is very original in the history of philosophy, because before Augustine the relation of faith to reason and especially the subject of faith had not been discussed so elaborately. In the history of thought the subject of faith firstly with Christianity enter into philosophy and the person who discussed this subject in philosophical context so deeply was Augustine. In the history of humanity firstly Augustine united religious faith and knowledge in a melting pot and after Augustine untill today in Christian World these two areas have never seperated from each other. At this point, I think, Christian World is very lucky, because they are indebted their scientific and cultural development to this synthesis of faith and reason (secular reason of Ancient Greek). The nations who could not comprehend reason of Ancient Greek and could not unite this reason with their religious faiths have not realized any important development in scientific and cultural areas. So they are sentenced to being slave by themselves.

\footnotetext{
1 Paul Helm, Ibid., p. 9-10.

${ }^{2}$ R. H. Nash, Ibid., p. 28.

3 lbid.,p.28-29.
} 


\section{The Relation Of Belief To Understanding}

The relation of belief to understanding is a subject which originates from the structure of belief and knowledge. The relation in question is important especially in the context of religious belief. "Augutine his Soliloquies with the confession that the two things he wants to know are his soul and God. In the second book of De Libero Arbitrio, Augustine says to his interlocutor, Evodius: 'At any rate you are quite certain that God exist.' Evodius replies, 'I firmly believe it, but I do not know it,' a characteristic Augustinian idea, which is later picked up by St. Anselm. This section ends with Evodius' saying 'but we want to know and understand what we believe."1 The search of understanding Evodius mentioned composes the basis of the problem. John M. Rist indicates this issue saying that "the limitations of 'certain knowledge'compelled Augustine to a radical re-evaluation of the philosophical status of belief and its relation to understanding." ${ }^{2}$

At this point we want to attract attention to an other original aspects of Augustine. Bubacz states this originality associating it with contemporary philosophy: "Augustine's understanding of knowledge is opposite to the contemporary empirical understanding. Contemporary empirical understanding allocates knowledge to the assertions which are believed by people depending upon a robust evidence when they are true. However, basic knowledge is belief. Belief is necessary, because it's antecedent to understanding temporarily." ${ }^{3}$ Because he dealt with these issues in a philosophical ground thoroughly, Augustine may be thought as the source of the tradition of faith looking for understanding.

In the frame of relation of belief to knowledge, one of the issues Augustine treated was priority of belief to understanding or knowledge. "'First believe, then understand' is a theme that recurs throughout Augustine's writings. 'We believed that we might know; for if we wished first to know and then to believe, we should not be able to know or to believe.' Augustine does not mean by this that we begin with faith and then go on to knowledge. He is teaching, instead, that we must believe in order to know. Faith, in a sense, is a precondition of knowing." ${ }^{4}$

This situation we mentioned above paragraph goes for not only spiritual themes, it goes for also the themes which are not spiritual. When he deals with these issues, Nash gives that explanation of Augustine as an argument: "Thus, although we can see bodies with our physical eyes and see our own thoughts and will by the eyes of our mind, we cannot see the minds of other people. Yet no Manichean seriously maintains that other people have no minds; he sees their physical actions and hears their words, but he takes it for granted that they have minds. This, Augustine informs him, is not sight but faith. 'Will you haply say that you see the will of another through his Works? Therefore you will see acts and hear words, but, concerning your friend's will, that which cannot be seen and heard you will believe." 5

One of the benefits of such that kind of belief is that it also provides understanding in daily life. Augustinus states this by saying "credo ut intelligam" 6 (I believe so that I might understand). Burt, as parallel to Nash, appreciates the wordly and religious importance of the contribution of this belief: "Even on the humble level of everyday living, belief opens the door to great vistas of knowledge that we only later come to understand. A baby left to its own direct experience and purely personal interpretation of it would not progress far in accurate knowledge of reality. Probably none of us would have survived without the trust we developed in the friendly giants who were constantly telling us what was and was not good for us. And when it comes to beatifying knowledge, that knowledge that is crucial for our eternal happiness, the priority of faith is even more important. In our present condition we cannot know much about God except by believing. Once we believe in the fact of Trinity, we can then go onto try to understand what the mystery means."

In fact the concept of faith may seem to indicate every time to the spiritual world, it nourishes from the material world. "Although understanding lies in the sight of Eternal, faith nourishes with milk in the cradles of temporal things. Now 'we walk by faith and not by sight'. Unless we walk by faith, we shall not be able to come to that sight which does not fail but continues through a cleansed understanding uniting us with Truth. On account of this principle one said 'If you will not believe, you shall not continue,' and another said, 'If you will not believe, you shall not understand. Therefore do not seek to understand in order that you may believe, but believe in order that you may understand." 8 Helm interprets quotation

\footnotetext{
1 Gareth B. Matthews, "Knowledge and Illumination", The Cambridge Companion to Augustine, Cambridge 2006, p. 182.

2 John M. Rist, Ibid., p. 56.

3 Bruce Bubacz, St. Augustine's Theory of Knowledge, A Contemporary Analysis, New York 1981, p. 124.

${ }^{4}$ R. H. Nash, Ibid., p. 26.

5 Ibid., p.26.

${ }^{6}$ Augustinus, De Libero Arbitrio II, 2, 6; Epistolae 120, 1, 3.

7 Donald X. Burt, Ibid., p. 46.

8 Paul Helm, Ibid., p. 26-27.
} 
above that he gave from Augustine like that: "In these slogans sometimes the stress is placed not on the understanding as the outworking of faith, as what faith leads to, but on faith as the condition of understanding; if I want to understand, I must first believe. It is as if faith involves or posseses no understanding itself but is purely functional or instrumental. Though as we shall shortly see matters are not quite as straightforward as that. Now it is faith to believe that which you do not yet see; and the reward of this faith is to see that which you believe. Here faith is contrasted not with understanding but with sight, and the reward of faith is equated with seeing, not vision in the strict sense, but with direct or immediate knowledge of the sort that vision conveys. As we noted, one thing that Augustine has in mind is the biblical contrast between faith and sight. Faith, unlike sight, is at best indirect; or perhaps it is more accurate to say that it is less direct than sight. Understanding makes faith more direct, more like sight, than it would otherwise be."1

It is necessary to come up to the act of understanding and knowing after act of belief. "Because we want to understand and know what we believe in," ${ }^{2}$ and there are positive effects that these acts of understanding and knowing add to the belief. "The understanding does not consist simply of gaining additional evidence for the belief in order to justify it, but in understanding the grounds of belief, or the meaning of what is believed, or both, better." ${ }^{3}$ Again, making a quotation from Augustine, Helm interprets like that this mutual dependance of belief and knowledge to each other: "I considered the innumerable things I believed which I had not seen, events which occurred when I was not present, such as many incidents in the history of the nations, many facts concerning places and cities which I had never seen, many things accepted on the word of friends, many from physicians, many from other people. Unless we believed what we were told, we would do nothing at all in this life. Finally I realized how unmoveably sure I was about the identity of my parents from whom I came, which I could not know unless I believed what I had heard.' Augustine says that such trust of another person is not something that one could gain from experience but is itself a pre-condition of understanding and accepting much that we presently experience. How could I gain from experience the knowledge that $X$ and $Y$ are my parents? I need someone to tell me, since necessarily I could not, in infancy, have come to know such facts for myself, and I can not now reach back in time. The idea that one might, even in principle, get down to a bed-rock of experience each item of which one had personally verified is an illusion." 4 It seems here that Augustine affiliates understanding into the scope of philosophy of knowledge. According to Jeauneau, Augustinus formulated this situation by saying "Understand so that you might believe, believe so that you might understand." 5

According to Jeaneau, these thoughts of Augustine, on the contrary to the false beliefs, show that reason was not leaved aside in middle age philosophy and Augustine's these thoughts affected other thinkers who came after him. "Christian belief does not deactivate reason, does not thrust aside investigation, does not destroy thinking. For this reason the best minds of middle age will keep the Augustinian advice. Ofcourse all of them didn't show the same consistency in conforming their knowledge and belief. According to this scheme, The situation of a Christian thinker takes place in movement with three times: In the point of departure there is a belief which believe without seeing anything, at the point of destination there is contemplation of a person who see but don't believe, between them is belief searching for understanding. Here, philosophy is that search. Neither church fathers nor middle age peopple had the anxiety of making seperation between these disciplines that today we make. They were going to the truth with all their sincerity and if they had make philosophy, they were doing this as blieving peoples. Except a small group, it didn't come to their mind to construct a temple of wisdom whose base did not Christian." 6

Nash says that in connection with religious faith the priority of belief to knowledge is connected to a passage from Holy Bible. According to Nash' quotation, "For some kinds of things are those which we do not believe, save we understand them; an other kinds of things are those which we do not understand, save we believe them. For since 'faith cometh by hearing, and hearing by the Word of Christ' (Rom. 10:17), how can one believe him who preaches the faith, if he-to say nothing of other points-understands not the very tongue which he speaks? But unless, on the other hand, there were some things which we can not understand, unless we believe them first, the prophet would not say, If you will not believe, you shall not understand."7

\footnotetext{
1 Ibid., p. 27.

${ }^{2}$ Augustinus, Sermones 43.

${ }^{3}$ Paul Helm, Ibid., p. 16.

${ }^{4}$ Ibid., p. 20-21.

${ }^{5}$ Edoward Jeauneau, Orta Çağ Felsefesi, trans. Betül Çotuksöken, p. 15, 1998, İstanbul.

6 Ibid., p.15-16.

${ }^{7}$ R. H. Nash, Ibid., p. 33.
} 
According to Helm, Augustine sometimes reverses the relation of belief to understanding. Depending upon a quotation from Sermones, Helm explains this situation like this: "My opponent too... has something when he says: 'I would understand in order that I may believe. Certainly what l' am now saying, I say with the object that those may believe who do not yet believe. Nevertheless, unles they understand what I am saying, they cannot believe." ${ }^{1}$ Here understanding is a condition of having faith. These seemingly contrdictory claims, that undersatnding follows faith and that understanding is needed for faith, can be reconciled if we bear in mind Augustine's view of faith. Faith has some cognitive content; and so a person needs to have some understanding of this content in order to have faith; otherwise how would his faith in God be distinguishable from faith in anyone else? It is this initial understanding which directs what what ought to follow; the understanding that is to follow keeps to the parameters of the basic cognitive content of faith and attempts to fill out the detail and so deepen the understanding. For the primary cognitive content of faith is limited; and so understanding gains a fuller appreciation of this content without going outside its limits. ${ }^{2}$

Giving one example, Helm tries to make clear Augustine's thought concerning to the relation of faith to understanding. According to Helm, "in this words Augustine makes clear that faith involves some understanding, for understanding is a necessary condition of faith, and that the understanding which faith then seeks is further understanding, building upon the primary understanding involved in the first steps of faith. Perhaps what Augustine takes to be the primary understanding of faith is not the direct comprhension of spiritual realities, but the understanding of words. What Augustine is saying is that it is necessary for anyone who believes anything first to have a form of words proposed for their belief, just as a novice joiner may believe that he needs a set-square without knowing what a set-square it. And then a fuller comprehension may follow this believing, a graeter awareness of those realities which the language of their faith denotes and connotes. To understand is thus more than comprehending the meanings of words, it is an appreciation of thoso realities which the words represent." 3

At this point, it appears that there are two situations of faith-understanding relationship: The priority of faith/belief to understanding and the priority of understanding to faith. We should examine them in relation to each other. "Belief is a necessary means to beatification but it is not meant to be the ultimate stage in our knowing. We believe now so that someday we can come to a time and a place where we will finally and forever understand ourselves and our God. We seek now by faith; then we shall find by understanding. Then we shall know the truth of Augustine'words: Understanding is the reward of faith. Then we shall finally see what now we can only believe." 4

Stephen Mann also signifies to that relationship. According to him, "thus we must begin by believing what we read in scripture, and then press on to undestand it. This means, most obviously, to know or understand that it is true; but for Augustine, much of the difficulty lies in the preliminary task of undestanding what it means." ${ }^{5}$ By saying "in the areas of immediate knowledge too, one should firstly believe before understanding," 6 Nash enlarges the function of belief. However, "the ability to reason is a necessary condition for believing... No one can believe what he does not understand." ${ }^{\text {A Augustine }}$ was aware of this mutual relationship of faith and understanding as far as we understand from his writings.

In In Johannis Evangelium he says: "We believe that we might know; for if we wished to know and the believe, we should not be able either to know or believe." ${ }^{8}$ In Epistolae "but faith gives the understanding access to these things, unbelief closes the door," ${ }^{9}$ he says. Norman Geistler gives this quotation to exemplify this stuation: "But unless, on the other hand, there were somethings which we cannot understand unless we first believe them, the prophet would not say, 'If you will not believe, you shall not understand"' 10

These quotation from Augustine may help us best to put forth the relationship between these concept: "However I also believe all things that I understand, but I don't know all things that I believe. Because I know every tings that I

\footnotetext{
1 Sermones 43.

2 Paul Helm, Ibid., p. 27-28.

3 Ibid., p. 28

${ }^{4}$ Donald X. Burt, Ibid., p. 46.

5 Stephen Menn, Ibid., p. 193.

${ }^{6}$ R. H. Nash, Ibid., p. 29.

7 Ibid., p. 30.

${ }^{8}$ Augustinus, In Johannis Evangelium XXVII, 9.

${ }^{9}$ Epistolae 137, 4.

10 Norman Geisler, What Augustine Says, p. 16. Oregon, 1982.
} 
understand. Although most of the things left unknowable for me, I know the benefits of belief." "In this situation we are indebted to reason what we understand, what we believe in to authority and on what we have estimation to mistake."2

\section{Afterword}

In the beginning we stated that the relations of these conceps in question depend upon the limited structure of reason. As far as we can understand, Augustine paid attention to this situation and he opposed to all kinds of irrationality. That he makes emphasis on the funstions of belief and priority of belief in some situations does not mean that he is an irrationalist. From the point of relation of belief to knowledge, Burt explains this situation like that: "It was impossible for Augustine to be either a pure fideist because he was convinced that understanding and belief were intertwined, each depending on the other. If we were not beings of reason with a hunger to know, we could not come to belief. Recognition of the need to believe rests on reason's awareness of its own limits. Recognition of possibility of belief rests on reason's acceptance of the proposed truth as at least believable. Finally, for belief to be truly well-founded there must be some rational analysis of the credentials of the authority on which the belief is based. In all of these ways reason seems to have priority over faith and justifies the truth of Augustine's assertion that: Intelligo ut credam (I understand so that I might believe)." ${ }^{3}$

However the act of beliving provides some advantages to believer that unbelievers cannot have any time. Belief provide for believer entrance ticket to enter into some areas. "He who does not believe will not understand. For he who does not believe will not experience, and he who has not had experience will not know. For the knowledge of the one who experiences is superior to the knowledge of the one who hears, to the same degreee that experience of a thing is superior to hearing about it." 4

On the other hand faith is not an act realised blindly. "Faith is assent to a proposition in virtue of its having been put forward by an authority one has accepted on rational grounds, so that the understanding which faith then seeks is of a piece with the primary understanding which is required to make the propositions initial act of faith credible. Understanding is assent to a proposition in virtue of its having been clarified or supported (or both) by one's reason on the basis of analysis and argument. Such clarification would involve, for example, the removal of ambiguities which make for misunderstanding, the drawing out of logical implications of the proposition of faith, and the rebutting of prima facie reasonable objections to the meaningfulness or the truth of such propositions." ${ }^{5}$ Besides, "what the gaining of understanding provides, insofar as it is achieved, is an increasigly informed acquaintance with the one who is, initially, trusted in faith, and so a richer experience. Here the dominant contrast is between faith and vision, or faith and sight; between the gradual replacement of what is indirect with what is direct as when, having had a letter from someone, I then meet them and make their acquaintance directly and more fully. One might even say that the personal trust of faith provides the one who trusts with a minimal direct acquaintance, as the one who receives a personal letter is minimally directly acquainted with the sender, in friendship, a person may come to know his friend better and better." ${ }^{6}$

If we think so, knowledge and faith will not contradict to each other. "Knowlede, even the incomplete knowledge of this life, is not incompatible with faith, because faith for Augustine is not primarily belief, but it is primarily reliance upon what is known; it is the act of relying on what is known, as distinct from is trusting and departing from what is known. It is the role of faith to renew this natura for innate knowledge of God. What reason gives is a clarification and intensification of a persons own natural and direct (non-inferential) knowledge of God. Faith is thus at least partly a moral agency; through it the perversity of the will is progressively removed, a perversity which until it is fully removed blocs further knowledge. As it is removed, the knowledge progresses through love of object of faith and increased acquainted with it, in a sort of reciprocal, upward spiral."

\section{BIBLIOGRAPHY}

1-Augustinus, De Libero Arbitrio.

\footnotetext{
${ }^{1}$ Augustinus, De Magistro XI.

2 Augustinus, De Utilitate Credendi XXV.

3 Donald X. Burt, Ibid., p. 46.

${ }^{4}$ Paul Helm, Ibid., p.40.

5 Ibid., p. 37.

6 Ibid., p. 10.

7 Ibid., p. 45.
} 
2 Epistolae.

3------, Sermones.

4---------, De Civitate Dei.

5 --------, In Johannis Evangelium.

6- --------, De Magistro.

7 --------, De Utilitate Credendi.

8 ------, De Trinitate.

9- -.---, Contra Academicos.

10---------, Contra Faustum Manichaeum.

11----------, De Vera Religione.

12------, De Genesi Ad Litteram.

13-Menn, Stephen, Descartes and Augustine, 2002, Cambridge.

14-Schmitt, Charles B., Schmitt, Cicero Scepticus: A Study of The Influence of The Academica in the Renaissance, The Hague, Martinus Nijhoff, 1972.

15- Nash, Ronald H., The Light of The Mind: St. Augustine's Theory of Knowledge, Ohio 2003.

16-O'Daly, Gerard, "The Response to Scepticism and the Mechanism of Cognition", The Cambridge Companion to Augustine, Cambridge 2006.

17-Rist, John M., Augustine, Ancient Thought Baptized, Cambridge, 1997.

18-Burt, Donald X., Augustine's World, London, 1996.

19-Helm, Paul, Faith and Understanding, Michigan 1997.

20- Clark, Mary T., "De Trinitate", Cambridge Companion to A ugustine, Cambridge, 2006.

21-Rist, John M., Faith and Reason, Cambridge Companion to Augustine, Cambridge, 2006.

22- Matthews, Gareth B., "Knowledge and Illumination", The Cambridge Companion to Augustine, Cambridge 2006.

23-Bubacz, Bruce, St. Augustine's Theory of Knowledge, A Contemporary Analysis, New York 1981.

24-Jeauneau, Edoward, Orta Çağ Felsefesi, trs. Betül Çotuksöken, 1998, İstanbul.

25-Geisler, Norman, What Augustine Says,. Oregon, 1982.

26-Katz, Sheri, Memory and Mind, An Introduction to Augustines Epistemology, Spring Hill College.

27-Curley, Augustinus J., Augustine's Critique of Scepticism, A Study of Contra Academicos, New York 1997. 